\title{
Retraction: Alcohol consumption and hormonal alterations related to muscle hypertrophy: a review
}

\author{
Antonino Bianco ${ }^{1}$, Ewan Thomas ${ }^{1}$, Francesco Pomara ${ }^{2}$, Garden Tabacchi ${ }^{3}$, Bettina Karsten ${ }^{4}$, Antonio Paoli ${ }^{5^{*}}$ \\ and Antonio Palma'
}

\section{Retraction}

This article [1] has been retracted by the Editors due to extensive overlap with previously published work [2]. The Editors apologise for any inconvenience caused.

\begin{abstract}
Author details
${ }^{1}$ Sport and Exercise Sciences Research Unit, University of Palermo, Via Eleonora Duse, 2, 90146 Palermo, Italy. ${ }^{2}$ MEDEOR Research Institute, Via Emilio Salgari, 69, 90147 Palermo, Italy. ${ }^{3}$ Department of Sciences for Health Promotion and Mother-Child Care "G. D'Alessandro", University of Palermo, Via del Vespro 133, 90127 Palermo, Italy. ${ }^{4}$ Life and Sports Science, University of Greenwich, Central Avenue, ME4 4 TB, Chatham Maritime, UK.

${ }^{5}$ Department of Biomedical Sciences (DSB), University of Padova, Via Marzolo 3, 35131 Padova, Italy.
\end{abstract}

Received: 8 September 2014 Accepted: 8 September 2014

Published: 24 September 2014

\section{References}

1. Bianco A, Thomas E, Pomara F, Tabacchi G, Karsten B, Paoli A, Palma A: Alcohol consumption and hormonal alterations related to muscle hypertrophy: a review. Nutrition \& Metabolism 2014, 11:26.

2. Alcohol-Scientific Review on Usage, Dosage, Side Effects. Examine.com at http://examine.com/supplements/Alcohol/.

\footnotetext{
* Correspondence: antonio.paoli@unipd.it

${ }^{5}$ Department of Biomedical Sciences (DSB), University of Padova, Via Marzolo 3, 35131 Padova, Italy

Full list of author information is available at the end of the article
}

Submit your next manuscript to BioMed Central and take full advantage of:

- Convenient online submission

- Thorough peer review

- No space constraints or color figure charges

- Immediate publication on acceptance

- Inclusion in PubMed, CAS, Scopus and Google Scholar

- Research which is freely available for redistribution 